\title{
化膿連鎖球菌のビルレンス因子, $\mathrm{M}$ 蛋白の役割とその発現調節
}

\author{
岡 田 信 彦 \\ 東京大学医科学研究所 細菌研究部 \\ T108 東京都港区白金台4-6-1 \\ [受理 : 1996年 1 月 9 日]
}

\begin{abstract}
化膿連鎖球菌は上気道および皮膚において急性化膿性炎を起こすほか，近年においては毒素ショッ ク様症候群の起因菌として注目されている。本菌の病原性を規定する重要なビルレンス因子の $1 つ$ として M 蛋白が知られている。M 蛋白はトロポミオシン様構造を呈する菌体表層蛋白で，その役割 として多形核白血球による食菌作用から菌を防御することが古くから知られているほか，菌の皮膚・ 表皮細胞への付着に直接関与し，このとき表皮細胞上の membrance cofactor protein（MCP あるい は CD46）を宿主レセプターとして認識すること，さらにヒト血獎蛋白である H 因子，キニノーゲ ン, アルブミンおよび免疫グロブリンとの結合能を持つこと, などがわかってきている。また，その 発現は外界の二酸化炭素濃度に依存することが明らかにされている。
\end{abstract}

\section{は じめに}

化膿連鎖球菌（A 群連鎖球菌，Streptococcus pyogenes）はグラム陽性球菌で軽度から中程度の 急性限局性化膿性炎（扁桃炎・咽頭炎・膿痂疹な ど）を引き起こすほか，菌の産生する毒素により 丹毒や猩紅熱を，ときに続発症としてリウマチ熱 や急性系球体腎炎を若起する。近年，特に先進国 においては, 医療, 栄養, 衛生状態の改善により 猩紅熱やリウマチ熱の軽症化あるいは発生の減少 が見られるよらになり，化膿連鎖球菌感染による 重症例は極めて稀になっている。ところが， 1980年初頭から欧米各国に拉いて新たに本菌に よる敗血症, ショックおよび多臓器不全を伴う症

Nobuhiko OKADA

Role of the M Protein of Streptococcus pyogenes and Its Regulation

Department of Bacteriology, Institute of Medical Science, University of Tokyo, Tokyo 108
侯群が頻発し, 毒素ショック様症候群（toxic shock-like syndorome, TSLS）として認識される ようになった（1）。毒素ショック様症候群は高 頻度に軟部組織の壊死性炎症 (壊死性筋膜炎など) を伴い, 発病後は急速に全身状態が悪化, 多㵴器 不全を起こし，極めて高い死亡率を示している。 日本に拈いても1992年の清水らの報告（38）以 来, 全国各地から毒素ショック様症候群に関する 症例報告は増加傾向にあり，本菌による感染症の 再認識が必要となってきている（30）。

化膿連鎖球菌の病原性に関与する因子として, 萊膜 (43), 分泌性蛋白 (蛋白分解酵素, DNA 分解酵素，ストレプトキナーゼ，ヒアルロン酸分 解酵素, 発熱毒素, ストレプトリジン $\mathrm{O}$ 扣よび S）（3，11）执よび菌体表層蛋白 [C5a ペプチダー ゼ（42），免疫グロブリン結合蛋白 $(4,9 ， 12$ ， 15)，プラスミン結合蛋白 $(21,32), \mathrm{F}$ 蛋白 （13，14）および M 蛋白（7，31，37)]などが 考光らている。これらのらち M 蛋白は古くか 
ら菌の病原性を規定する重要な因子の1つであ ると考觉られてきた。近年の遺伝子工学の発展に よりグラム陽性菌である化膿連鎖球菌に打いても 遺伝子操作が可能となり，1980年後半から現在 に至るまで $\mathrm{M}$ 蛋白の分子レベルでの解析が急速 に進められてきている。本稿では, 化膿連鎖球菌 の M 蛋白の持つ機能と役割および $\mathrm{M}$ 蛋白遺伝 子の発現調節について最近の知見を紹介する。

\section{1. $M$ 蛋白の構造}

$\mathrm{M}$ 蛋白の大きさやアミノ酸配列は菌株間で大 きく異なることが知られている。その可変性によ り, 現在までに $M$ 蛋白には少なくとも 80 種以上 の血清型が認められている。また, 同一菌株間に おいても M 蛋白分子の大きさにはアミノ酸レベ ルで変異（size variation）が観察されて拉り，こ れは M 蛋白をコードする遺伝子領域内の相同組 換えによる欠失あるいは重複に基づくものである と考えられている。 $\mathrm{M}$ 蛋白の構造についてはい くつかの総説 $(7,31,37)$ で詳しく述べられて いるので，ここではその一般的な基本構造につい て簡単に説明することにする。 M 蛋白はトロポ ミオシンと類似した $\alpha$-helical coiled-coil 構造を 呈する二量体蛋白で, $\mathrm{N}$ 末端側にシグナルペプ チドを有し, 成熟した $\mathrm{M}$ 蛋白分子では $\mathrm{N}$ 末端側 から $\mathrm{N}$ 末端可变部 (非らせん領域, tandem repeat からなる A および B 反復領域を含む)，
反復配列保存領域（C 反復領域）までが菌体表層 に露出し，それより $\mathrm{C}$ 末端側の細胞壁領域，プ ロリンーグリシンースレオニンーセリン (PGTS) ドメインおよび疎水性アミノ酸からなる細胞膜貫 通ドメインは C 多糖体局在層, 細胞壁ペプチド グリカン層拉よび細胞膜を貫通し，その終末端

（細胞質側末端部）は細胞質側に局在する（図 1)。PGTS ドメイン内にはグラム陽性菌の表層 蛋白に共通して見られる膜結合ドメイン（LPXTGX 配列）が存在する。現在までに全アミノ酸 配列が決定された $M$ 蛋白についてその配列を比 較すると，異なる $\mathrm{M}$ 型間においては $\mathrm{N}$ 末端可変 部は相同性が注とんどないか非常に低いのに対し て，C反復領域执よび細胞壁領域を含む C 末端 側では此較的高い相同性が保持されている (7)。 $\mathrm{N}$ 末端可変部領域には $\mathrm{M}$ 蛋白のオプソニン抗体 を誘導するエピトープが存在し，その抗体により 菌は容易に貪食されるようになる。したがって， この領域における可変性は菌が宿主の免疫反応か らエスケープするために必要な機構であり, その 非相同性はこの領域が常に構造変化を繰り返して きた結果によるのであろら。また，後述するよう にC 末端側には菌にとって重要な機能ドメイン が存在する。そのため異なる菌株間に㨟いてもそ の配列がよく保存されていると考えられる。

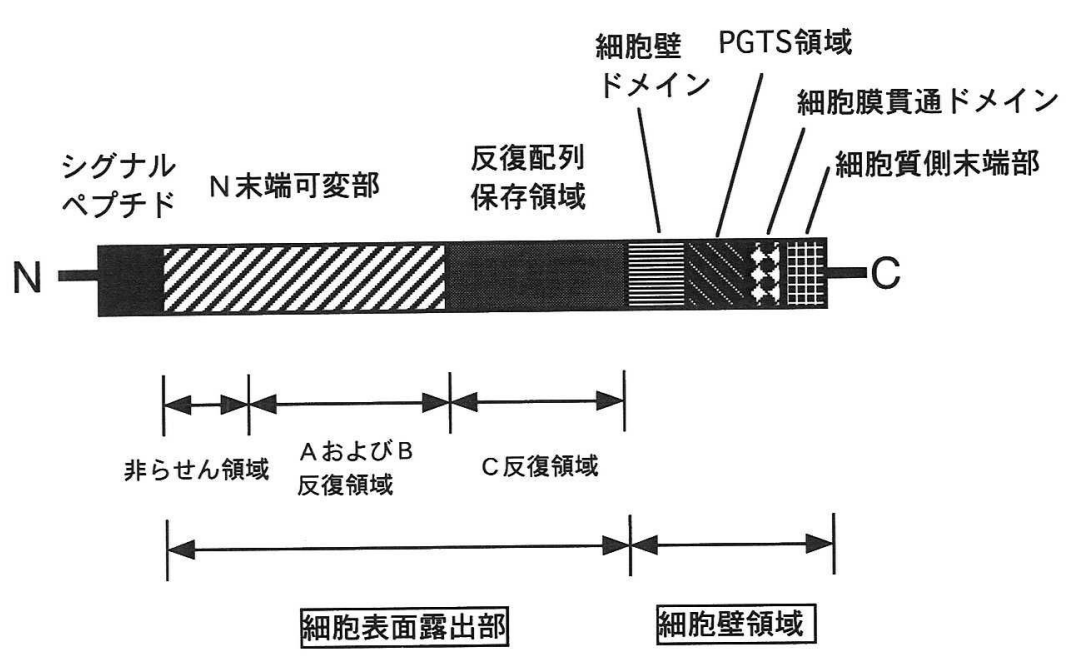

図 1. M 蛋白の基本構造。 


\section{M 蛋白による皮膚表皮細胞への付着}

化膿連鎖球菌の初期感染部位は上気道抒よび皮 膚である。上気道においては，菌の上皮細胞への 結合はフィブロネクチン結合蛋白である F 蛋白 が付着因子として働き，M 蛋白はこれに関与し ない（13）。一方，皮虐に执いては，菌一宿主細 胞に扮ける相互作用についてはこれまでほとえど わかっていなかった。我々は，6 型 $\mathrm{M}$ 蛋白

（M6 蛋白）を持つ野生株（JRS4）に対して isogenic な F 蛋白変異株 (SAM1), M 蛋白变異 株（JRS145）抗よび F・M 両蛋白変異株 (SAM2) の組み合わせによるヒトの皮膚組織切 片を用いた in situ 付着実験扣よび表皮初代培庰 細胞を用いた in vitro 付着実験の結果から，以下 のことを明らかにした（29）。1）M 蛋白を発現 する株は表皮の $90 \%$ 以上を占める表皮細胞に結 合するが，M 蛋白変異株では結合は見られない。 2）Ｍ蛋白変異株に M 蛋白遺伝子（emm6.1）を 戻すと表皮細胞への結合能を回復する。3）F 蛋 白を発現する株は表皮・基底細胞層に存在するラ ンゲルハンス細胞に特異的に結合する，4） F ・ $\mathrm{M}$ 両蛋白変異株は皮膚組織のいずれの細胞にも 結合しない。すなわち，化膿連鎖球菌は M 蛋白 により皮膚表皮細胞へ，また F 蛋白を介して抗 原提示細胞であるランゲルハンス細胞へ各々結合 する。そこで， M 蛋白分子上の表皮細胞への結 合に必要な領域を決めるために M6 蛋白の反復
ドメインを含さ種々の融合蛋白を作製した（図 2 )。これらの精製蛋白による菌の表皮細胞への 結合阻害実験から，C 反復領域を含む精製蛋白は 菌の表皮細胞への結合を特異的に阻害することが 明らかになった（28）。この結果を確認するため に，1つの C 反復領域のみを持つ $\mathrm{M}$ 蛋白を発現 する株（JRS237）あるいは完全にC 反復領域を 欠く $\mathrm{M}$ 蛋白を発現する株（JRS251）を作製し, 表皮細胞への結合能を野生型の M 蛋白を発現す る JRS236 株と比較した（図 3 )。ヒト表皮細胞 由来 HaCat 細胞に対して, JRS236 株が89\%の 付着率を示したのに対して JRS237 および JRS251 株はそれぞれ63\%と29\%であった（35）。 これらの結果から，M 蛋白による表皮細胞レセ プターの認識には C 反復領域が必要であること が示された。

\section{3 . M 蛋白に対する表皮細胞レセプター}

$\mathrm{M}$ 蛋白の C 反復領域は補体活性調節蛋白の 1 つ， $\mathrm{H}$ 因子 (factor $\mathrm{H}$ ) の結合ドメインであるこ とが知られている（後述）。我々は $\mathrm{M}$ 蛋白・C 反 復領域に H 因子が結合することにより菌の表皮 細胞への付着が阻害されることから, 同じ補体活 性調節蛋白である membrane cofactor protein （MCP，または CD46）が，M 蛋白に対する表皮 細胞レセプターであることを見い出した $(28)$ 。 補体活性調節蛋白は, 細胞表層蛋白 (Decay accelerating factor; DAF [CD55] と MCP), 膜

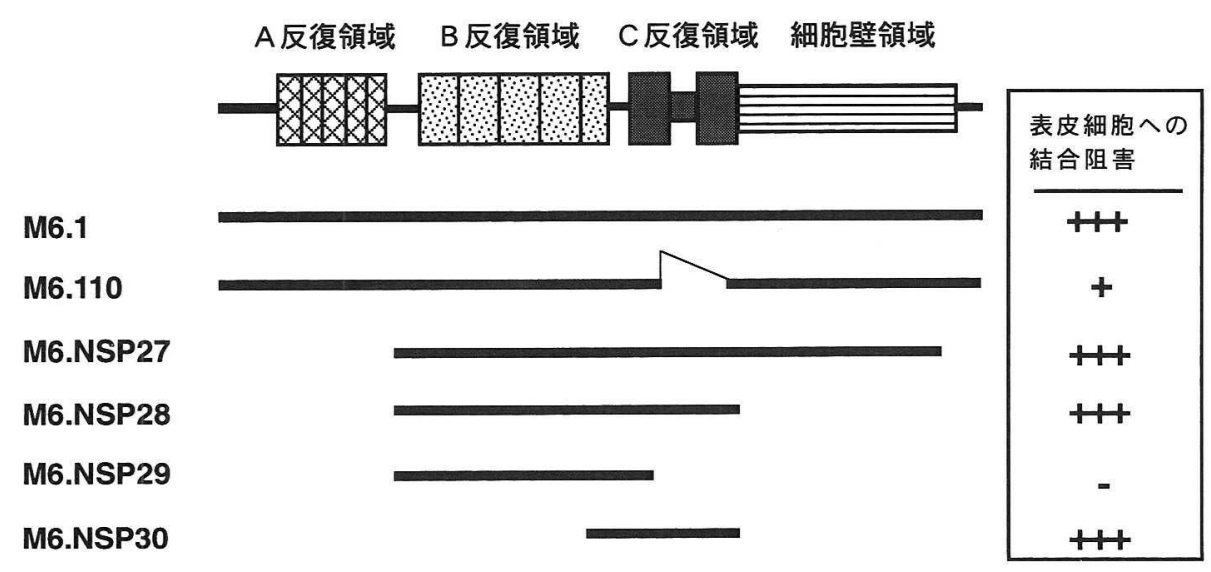

図 2. M6 蛋白の構造（上段）と精製 M6.1 蛋白とその部分蛋白を用いたヒト皮膚組織切片による菌の表皮細胞への 結合阻害実験の結果を示す。(文献28から改変) 
(A)

\section{$A$ 反復領域 $B$ 反復領域 C反復領域 細胞壁領域}

M 6.1

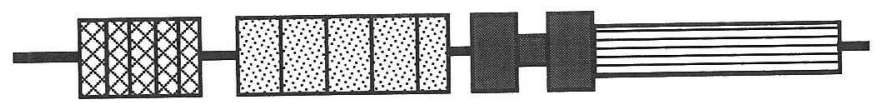

M6.110

M6.0117
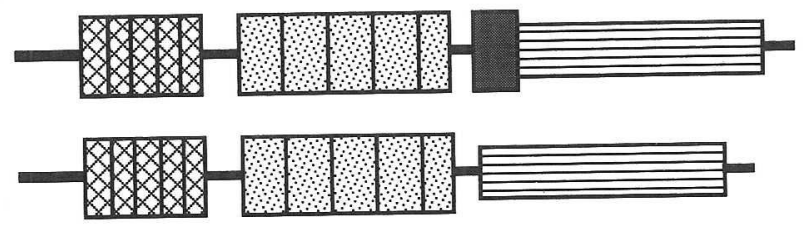

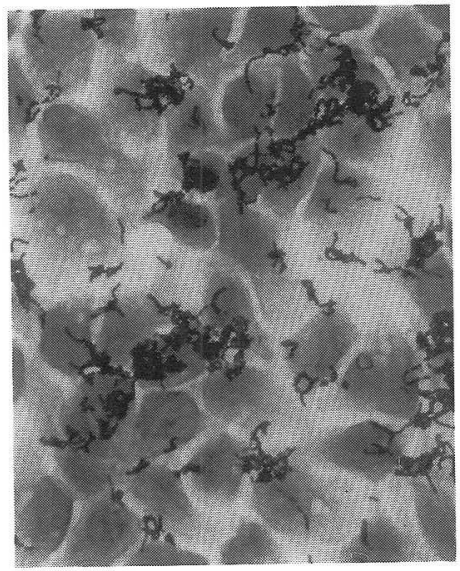

(B)

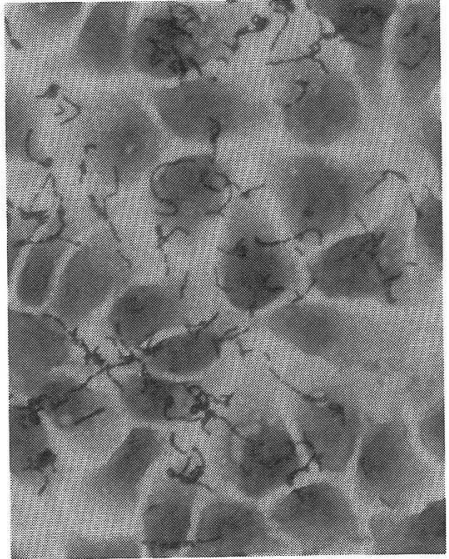

(C)

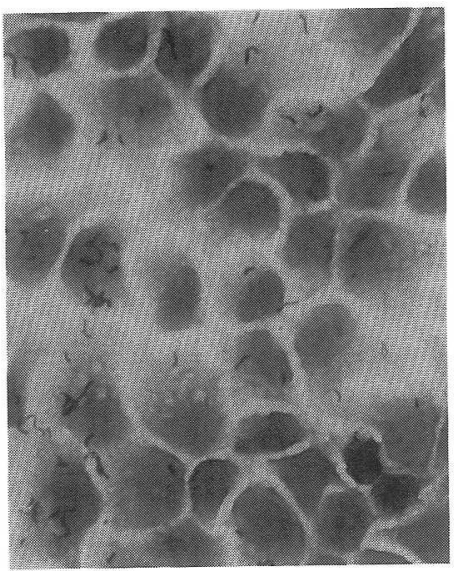

(D)

図 3. M6.1 蛋白および 2 つの C 反復領域欠失 M6 蛋白（M6.110 扰よび M6.0117）の構造（A）とそれらの M6 蛋 白を発現する化膿連鎖球菌 JRS236 (M6.1) (B), JRS237（M6.110）（C）打よび JRS251（M6.0117）(D) によ るヒト表皮細胞由来 HaCat 細胞への結合を示した。

セプター蛋白 (complement receptor type1; CR1 [CD35] と complement receptor type2; CR2 [CD21]）扣よび血清蛋白（factor $\mathrm{H}$ と C4 binding protein）として存在しこれらの蛋白はい ずれも short consensus repeat [SCR] と呼ばれる およそ60個のアミノ酸からなる複数の繰返し配 列を持つこと, $\mathrm{C} 3 \mathrm{~b} / \mathrm{C} 4 \mathrm{~b}$ と結合すること执よび これらの蛋白をコードする遺伝子は同一染色体上 でクラスターを形成することが知られている （17）。MCPは I 型膜結合性糖蛋白として細胞表 層に存在し，セリンプロテアーゼであるI因子に よる $\mathrm{C} 3 \mathrm{~b} の \mathrm{iC} 3 \mathrm{~b} へ の$ 变換の際の補因子（cofactor）として作用することで C $3 \mathrm{~b}$ にる自己の細 胞融解を抑制する働きを持つ $(20)$ 。この $\mathrm{MCP}$
は近年麻疹ウイルスの特異的レセプターとしても 注目を集めている $(10)$ 。我々は， $\mathrm{H}$ 因子が20個 の SCR 構造のみからなることからこの SCR 配 列が $\mathrm{M}$ 蛋白の結合に重要であると考光，4つの $\mathrm{SCR}$ 配列を持ら，広く上皮細胞に分布する $\mathrm{MCP}$ に注目した。ヒト皮膚組織切片上に和ける MCP の分布を免疫蛍光抗体法に上り観察すると, その 分布は M 蛋白による菌の付着部位とよく一致し ていた。そこで，MCP による菌の表皮細胞への 付着に対する影響を調べ，精製 $\mathrm{H}$ 因子蛋白と同 様に MCP 精製蛋白に执いても濃度依存的に菌の 表皮細胞への付着が阻害されることを明らかにし た（表 1 ）。さらに, MCP 蛋白を電気泳動後, ニトロセルロース膜に転写し, C 反復領域を含む 
表 1.H 因子执よび MCP による化膿連鎖球菌の表皮細胞への付着に対する影響

\begin{tabular}{|c|c|c|c|}
\hline \multirow[b]{2}{*}{ 阻害物質 } & \multirow[b]{2}{*}{ 濃度 $(\mu \mathrm{g} / \mathrm{ml})$} & \multicolumn{2}{|c|}{ 付着阻害率（\%) } \\
\hline & & HaCat 細胞 & 皮膚組織切片 \\
\hline PBS & - & 0 & 0 \\
\hline 牛血清アルブミン & $20 / 50$ & 0 & $1 \pm 8$ \\
\hline \multirow[t]{2}{*}{ H 因子 } & $2 / 5$ & $29 \pm 5$ & $32 \pm 9$ \\
\hline & $20 / 50$ & $56 \pm 3$ & $81 \pm 5$ \\
\hline \multirow[t]{2}{*}{$\mathrm{MCP}$} & $2 / 5$ & $31 \pm 4$ & $38 \pm 6$ \\
\hline & $20 / 50$ & $70 \pm 5$ & $77 \pm 6$ \\
\hline
\end{tabular}

菌を阻害物質で室温, 1 時間前処置後, HaCat 細胞あるいは皮膚組織切片を用いて付着実験を行った。付着阻害

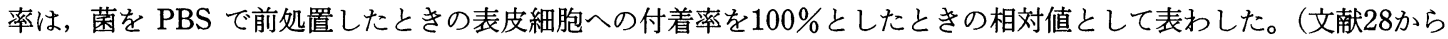
改変)

$\mathrm{M}$ 蛋白（図 2, M6.NSP30）と C 反復領域を欠 失した $\mathrm{M}$ 蛋白（図 2，M6.NSP29）とそれぞれ 反応すると, $\mathrm{C}$ 反復領域を含む $\mathrm{M}$ 蛋白は $\mathrm{MCP}$ と特異的に結合するのに対して C 反復領域を欠 失した $\mathrm{M}$ 蛋白は結合しなかった。これらの結果 から，MCP が M 蛋白（C 反復領域）に対する 表皮細胞レセプターとして作用することが明らか となった。

\section{M蛋白のヒト血漿蛋白に対する結合}

M 蛋白はヒト血墏中に含まれる $\mathrm{H}$ 因子（16） のほか, フィブリノーダン (44), 血清アルブミ ン（2）扣よびキニノーゲン（25）と結合するこ とが報告されている。また，一部の $\mathrm{M}$ 蛋白 (M1，M12，M49）は免疫グロブリンに対して も結合能を持つことが知られている（2）。

前に触れたように， $\mathrm{H}$ 因子は血清中に含まれ る補体活性調節蛋白の 1 つで, $\mathrm{C} 3 \mathrm{bBb}$ 複合体 （C3 コンバターゼ）の形成阻害あるいはこの複合 体を解離して I 因子依存性の $\mathrm{C} 3 \mathrm{~b}$ の $\mathrm{iC} 3 \mathrm{~b}$ への変 換の際の補因子として作用する。 $\mathrm{M}$ 蛋白分子上 に拈ける $\mathrm{H}$ 因子の結合ドメインの解析は M6 蛋 白により行われている。Fischetti ら（8）は， ペ プシン消化した M6 蛋白をアクリルアミド電気 泳動後, ニトロセルロース膜に転写し, 精製した $\mathrm{H}$ 因子との結合反応を行い，执よそ15 kDa の M6 ペプシン消化断片上に $\mathrm{H}$ 因子が結合するこ とを同定した。さらに, この断片は C 反復領域 を含むことから，その領域のアミノ酸配列をもと に部分ペプチドを合成し，M6 蛋白と H 因子と
の結合阻害実験を行った。その結果，スペーサー 領域（アミノ酸残基256番目から277番目）扣よ び C 2 反復ドメイン（アミノ酸残基 272 番目から 292番目）を含む合成ぺプチドによりそれぞれ $94 \%$ 执よび $89 \%$ の結合阻害が起こり，M 蛋白の $\mathrm{C}$ 反復領域が $\mathrm{H}$ 因子との結合に重要であること を示した。また，Perez-Casal ら（35）は前述の $\mathrm{C}$ 領域を欠く M 蛋白を発現する JRS251 株を用 いて，この株が $\mathrm{H}$ 因子結合能を喪失しているこ とを明らかにした。すなわち，M 蛋白の $\mathrm{H}$ 因子 結合ドメインが $\mathrm{C}$ 反復領域であるということを 直接的に示したことになる。

一方, $\mathrm{M}$ 蛋白とフィブリノーゲン, 血清アル ブミン，キニノーゲン执よび免疫グロブリンとの 結合ドメインの解析は M1 蛋白により行われて いる。Bjorckら（2，25）は 3 つの異なる M1 蛋 白の部分蛋白, $\mathrm{A}-\mathrm{C} 3$ 断片 $(\mathrm{A}, \mathrm{B}, \mathrm{S}$ 打よび $\mathrm{C}$ 領域を含む)， A-S 断片（A， B および $\mathrm{S}$ 領域を 含む) および S-C3 断片 (S および C 領域を含む) を大腸菌内で発現, 精製し, 各蛋白との結合能括 よび各蛋白間での結合阻害実験を行い，それぞれ の蛋白の M1 蛋白との結合ドメインを決定した (図 4)。すなわち，フィブリノーゲン执よびキ ニノーゲンは $\mathrm{A}$ 拉よび $\mathrm{B}$ 反復領域, 免疫グロブ リン $\mathrm{G}(\mathrm{IgG})$ は $\mathrm{S}$ 領域, 血清アルブミンは $\mathrm{C}$ 反 復領域に結合することを明らかにした。また，フ ィブリノーゲン拉よびキニノーゲンはそれぞれ M1 蛋白との結合に拮抗しないことから A 拉よ び $\mathrm{B}$ 反復領域内の異なる部位に結合するものと 推定されている（25）。 


\section{M1 蛋白}

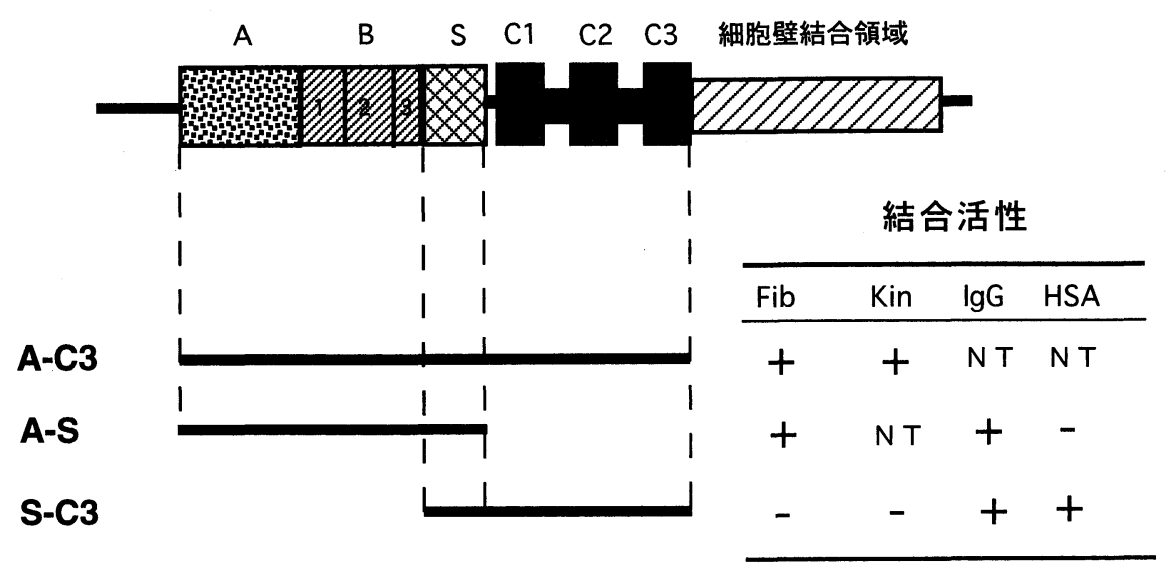

図 4. M1 蛋白の構造（上段）とその精製部分蛋白による種々の血墏蛋白との結合能。Fib；フィブリノーゲン， Kin ; キニノーゲン, IgG ; 免度グロブリン G, HSA ; ヒト血清アルブミン。

\section{5. 食菌抵抗性因子としての $M$ 蛋白}

M 蛋白を発現する株が多形核白血球による食 菌作用に対して抵抗性であり，M 蛋白を欠く菌 は容易に貪食されるといら事実は古くから知られ ていた（19）。ところが，このことが分子遺伝学 的に証明されたのは1990年代に入ってからであ った。Scott らは, 野生株 JRS4 由来の M6 蛋白 遺伝子（emm6）を含む染色体 DNA 断片に执い て emm6 遺伝子をカナマイシン耐性遺伝子, $a p h A 3$ と置換党，伝達性トランスポゾン Tn916 上に挿入後, 枯草菌に形質転換した。これを枯草 菌から野生株 JRS4 に接合伝達し, 相同組換えに よりカナマイシン耐性の $\mathrm{emm} 6$ 欠失変異株, JRS75 を作製した（26）。さらに，エリスロマイ シン耐性遺伝子 $(\mathrm{erm} A M)$ を選択マーカーとし て JRS4 由来の $e m m 6$ 遺伝子を JRS75 株の染色 体上の $a p h A 3$ 遺伝子と相同組換えにより再度置 換え, エリスロマイシン耐性の M 蛋白発現株 （JRS115）を作製した（図 5 ）（34）。この3つ
J R S 4
染色体

J R S 75 染色体

J R S 115 染色体

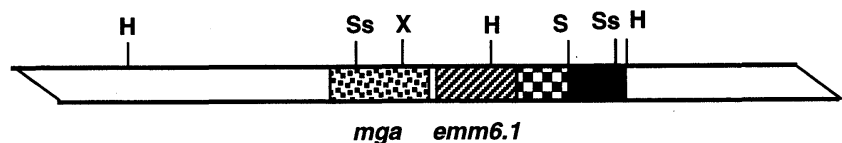

mga emm6.1

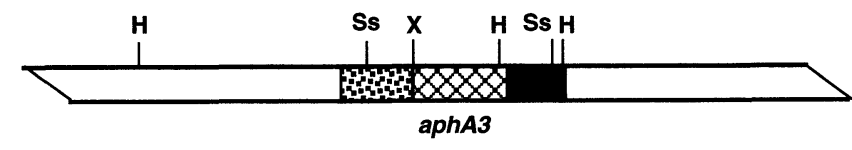

aphA3

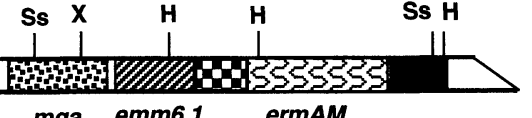

$M$ 蛋白の発現 食菌抵抗性

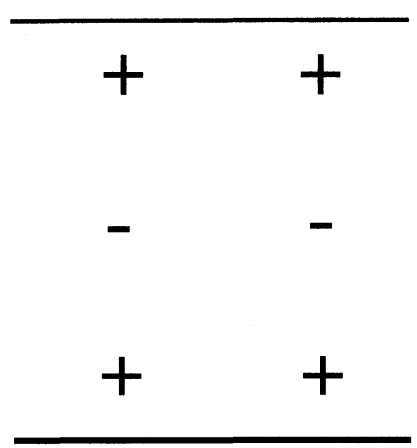

図 5.M 蛋白の発現と食菌抵抗性との関係。野生株 JRS4，M 蛋白欠失株 JRS75 およびその M 蛋白遺伝子挿入株 JRS115 の染色体 M 蛋白遺伝子領域の部分制限酵素地図を右側に示した。aphA3；カナマイシン耐性遺伝子， ermAM; エリスロマイシン耐性遺伝子, emm6.1; M 蛋白遺伝子, $m g a$; Mga 蛋白遺伝子。制限酵素部位, $\mathrm{H}=$ HindIII, $\mathrm{S}=S a l \mathrm{I}, \mathrm{Sp}=S s p \mathrm{I}, \mathrm{X}=X b a I$ 。 
の isogenic な株について，ヒト血液を用いた食 菌抵抗性試験を行った。M 蛋白を発現する JRS4 は多形核白血球による食菌作用に対して抵抗性を 示すのに対して, M 蛋白変異株, JRS75 は食菌 抵抗性を喪失していた。また，この株の染色体上 に emm6 遺伝子を戻した $\mathrm{M}$ 蛋白発現株, JRS115 は野生株同様, 食菌抵抗性を回復してい た（34）。すなわち，本菌の食菌抵抗性は $\mathrm{M}$ 蛋 白の発現に依存寸るといらことが初めて遺伝子レ ベルで証明されたことになる。

$\mathrm{M}$ 蛋白による食菌抵抗性は, $\mathrm{M}$ 蛋白に $\mathrm{H}$ 因子 が特異的に結合することにより菌体表面に付着し た C3b の I 因子による不活化，あるいは $\mathrm{C} 3 \mathrm{bBb}$ 複合体の形成阻害ないし解離促進により $\mathrm{C} 3 \mathrm{~b}$ を 介した好中球による菌体の貪食を阻害すると考兄 られてきた（16）。ところが，C 反復領域を欠く M 蛋白を発現する JRS251 株は H 因子結合能を 亦失しているにもかかわらず，ヒト血液を用いた 食菌試験で抵抗性を示した（35）。すなわち，M 蛋白による食菌抵抗性に対して $\mathrm{H}$ 因子は関与し ないことが明らかになった。 M 蛋白による食菌 抵抗性に関してはそのほか， M 蛋白がフィブリ ノーダンと結合することによりリポタイコ酸など の補体活性化成分をフィブリノーゲンが被覆す る, あるいは M 蛋白に結合したフィブリノーゲ ンが補体レセプターの認識を阻害し, 菌を食菌作 用から防御するといら可能性も考えられている

(44)。いずれにせよ，M 蛋白による食菌抵抗性 に関してその作用メカニズムについては不明のま まであり，その解析は今後の課題として残ってい る。

\section{6 . 二酸化炭素による M 蛋白の発現調節機構}

多くの病原細菌において菌のビルレンス因子は 感染の各段階で宿主側の環境変化に応じて合目的 に発現され，それぞれ重要な役割をはたしている ことが明らかになってきている $(6,23)$ 。すな わち, 菌はある特定の宿主環境下に特いて, ある 特定の物質を感知し，シグナル伝達することによ って菌の生残に必要な遺伝子の発現を促進する。 化膿連鎖球菌に拈いても，M 蛋白の発現はその 正の調節因子である Mga 蛋白（Mry あるいは VirR と呼ばれていた）による二酸化炭素濃度依
存的な調節を受けている。Caparon ら（5）は, $\mathrm{M}$ 蛋白遺伝子 (emm6.1) のプロモーター領域の 下流に Bucillus pumilis 由来のクロラムフェニ コールアセチル化酵素遺伝子（cat86）を接続し

（図 6,JRS145）, 培養条件の違いによる M 蛋 白遺伝子のプロモーター活性の変化をクロラムフ ェニコールアセチル化酵素（CAT）活性により 調べた。その結果, JRS145 株の CAT 活性は液 体培地で $37^{\circ} \mathrm{C}, 18$ 時間静置培養した場合, 同様 に固形寒天培地上で培養したときの扣よそ30倍 であることを見い出した。液体および固形培地に 打ける M 蛋白遺伝子のプロモーター活性の違い は, 両培地間の $\mathrm{pH}$, 酸素あるいは二酸化炭素濃 度などによる違いに起因すると推定された。そこ でまず，両培地に拉ける $\mathrm{pH}$ の変化を調べると， ともに18時間培養後には7.6から6.0亿低下して拉 り違いは見られなかった。次に菌を異なる酸素お よび二酸化炭素濃度条件下の寒天培地上で培養し, CAT 活性を測定すると, 通常の大気中 $\left(20 \% \mathrm{O}_{2}\right.$, $0.03 \% \mathrm{CO}_{2}$ ) で培養したときの CAT 活性を 1 と したとき，二酸化炭素濃度が増加すると（20\% $\left.\mathrm{O}_{2}, 10 \% \mathrm{CO}_{2}\right) 14$ 倍, 酸素濃度を減少させると $\left(5 \% \mathrm{O}_{2},<0.1 \% \mathrm{CO}_{2}\right) \quad 4$ 倍, 酸素濃度を減少 させた状態で二酸化炭素濃度を増加すると（5 $\% \mathrm{O}_{2}, 10 \% \mathrm{CO}_{2}$ ) 20倍であった（図 6 )。すな わち, M 蛋白遺伝子の発現は二酸化炭素濃度の 上昇に伴い増加することがわかった。また，この ことから, 液体培地に拈ける $\mathrm{M}$ 蛋白遺伝子のプ 口モータ一活性の上昇は, 培地中への二酸化炭素 ガスの拡散増加によるものと推定された。

一方, $\mathrm{M}$ 蛋白遺伝子の発現はその上流に位置 する $m g a$ 遺伝子によって転写レベルで正の発現 調節を受けている (33)。 $m g a$ 遺伝子の発現には 少なくとも $m g a$ 遺伝子から $473 \mathrm{bp}$ 上流の DNA 領域が必要で, この領域の中に 2 つのプロモー ターが存在する。また, $m g a$ 遺伝子は自己調節 遺伝子であり, $m g a$ 遺伝子の発現には Mga 蛋白 の存在が必要である (27)。JRS145 株の mga 遺 伝子を不活化した株（JRS150）は高二酸化炭素 条件下で培養した場合においても CAT 活性の増 加は見られない（図 6 )。このことは, 二酸化炭 素濃度に依存した $\mathrm{M}$ 蛋白の発現は $m g a$ 遺伝子を 介して調節されている可能性を示唆している。我 

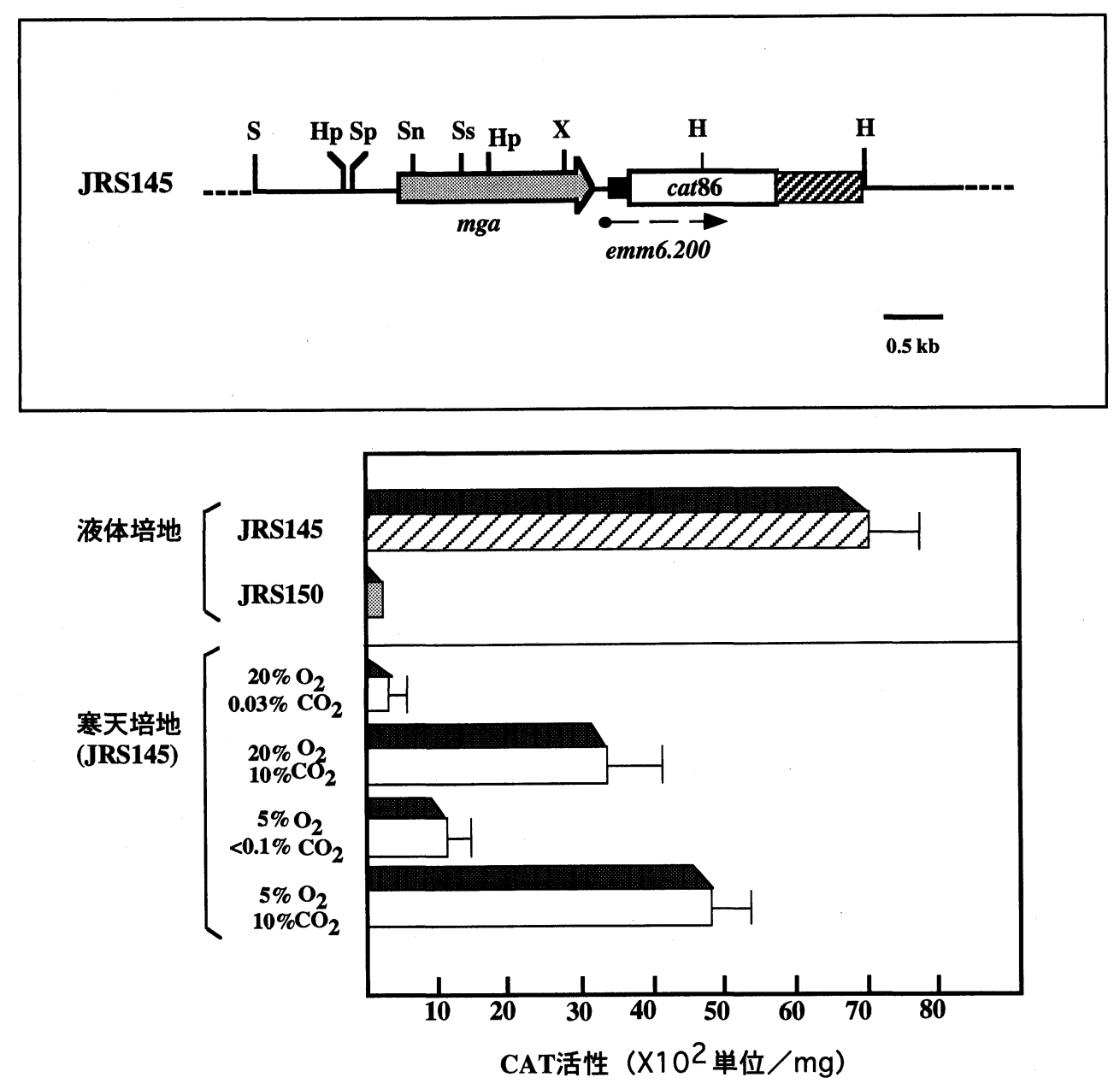

図 6.JRS145 株における M 蛋白遺伝子の二酸化炭素による発現調節。Bucillus pumilis 由来のクロラムフェニコー ルアセチル化酵素遺伝子 (cat86) を M 蛋白遺伝子 (emm6.1) のプロモータ一領域下流に接続した emm6.200 を有する JRS145 株の染色体部分制限酵素地図（上段）。制限酵素部位， $\mathrm{H}=H i n \mathrm{dIII}, \mathrm{Hp}=H p a \mathrm{I}, \mathrm{S}=S a l \mathrm{I}$, $\mathrm{Sn}=S n a \mathrm{BI}, \mathrm{Sp}=S s p \mathrm{I}, \mathrm{Ss}=S s t \mathrm{I}, \mathrm{X}=X b a I$ 。下段は JRS145 株を THY 液体培地あるいは異なる酸素および二 酸化炭素濃度下に拉ける寒天培地上で培養したときの CAT 活性の結果を示した。JRS150 は JRS145 株の mga 遺伝子を $\Omega \mathrm{Km}-2$ 断片により挿入不活化することにより作製した。（詳しくは文献 5 を参照）

々は, $m g a$ 遺伝子に cat86 遺伝子を接続し, $\mathrm{M}$ 蛋白遺伝子の場合と同様の実験を行い, $m g a$ 遺 伝子のプロモーター活性が二酸化炭素濃度の増加 に伴い上昇することを明らかにした $(24)$ 。すな わら，M蛋白の発現は二酸化炭素濃度に依存し ており，外界の二酸化炭素濃度が上昇することに より $\mathrm{M}$ 蛋白遺伝子の正の調節遺伝子である $m g a$ 遺伝子の発現が活性化され, その結果, $\mathrm{M}$ 蛋白 の発現が促進されると考兄られた。そのほか，M
蛋白遺伝子のプロモーター活性に影響を与える環 境因子として温度, 浸透圧, 鉄イオン濃度などが 報告されている $(22)$ 。

$$
\text { おわりに }
$$

これまでに，化膿連鎖球菌の表層蛋白で $\mathrm{M}$ 蛋 白と類似構造を持ついくつかの $\mathrm{M}$ 蛋白様蛋白 (M-like protein) あるいは M 蛋白関連蛋白（Mrelated protein）が同定されている。これらは, 
$\mathrm{M}$ 蛋白同様 $\alpha$-helical coiled-coil 構造を呈し, そ れぞれの蛋白は細胞壁結合領域を含む C 末端側 に高い相同性を保持している。また, これらの蛋 白をコードする遺伝子は $m g a$ 遺伝子の下流, C5a ペプチダーゼ産生遺层子 $(s c p A)$ の上流に 位置し, $m g a$ 遺伝子による調節下 $(m g a$ レギュ ロン) にある (36)。これら M 蛋白ファミリー のなかで $M$ 蛋白のみが食菌抵抗性を示す。

$M$ 蛋白は二酸化炭素濃度に依存してその発現 が調節されている。このことは, 化膿連鎖球菌の 感染過程に打いて, 好気的条件下にある宿主体外 あるいは表面に打いては $\mathrm{M}$ 蛋白の発現は抑制さ れ, 一方, 体表面から組織深部に侵入し, より嫌 気的条件下になると $\mathrm{M}$ 蛋白の発現は促進される と考えられる。M 蛋白を発現している菌は, 炎 症反応により遊走してきた多形核白血球による食 菌作用から回避し,さらに深部あるいは全身的に 拡散することが可能となる。すなわち，M 蛋白 は菌の感染初期よりもむしろ初期感染部位からさ らに感染の場を広げるために必要なビルレンス因 子の 1 つであると考兄られる。また, $m g a$ 遺伝 子は $\mathrm{M}$ 蛋白だけでなく，C5aペプチダーゼおよ び免疫グロブリン結合蛋白の発現にも正の発現調 節遺伝子として関与している $(36)$ 。したがっ て, 菌は $M$ 蛋白だけでなく他の表層蛋白も同時 に発現することにより宿主の成体防御機構から効 率よくェスケープし，全身的に広がることができ るのであろら。

最後に, 近年, 細菌感染に起因するいくつかの 疾患に颃いて菌の産生するスーパー抗原活性物質 がその発生機序に関与する可能性が強く示唆され ている $(18,39)$ 。化膿連鎖球菌に拈いては発熱 毒素 (streptococcal pyogenic exotoxin; SEP) 扣よび連鎖球菌性スーパー抗原（streptococcal superantigen ; SSA）がスーパー抗原活性を持つ 物質として報告されている（24）。興味深いこと に, Kotb らのグループはいくつかの M 蛋白 (M5, M6, M18, M19, M24) にもスーパー抗 原活性があることを見い出した $(40,41)$ 。スー パー抗原としての M 蛋白が病原性にどのように 関わっているのか今後明らかにする必要がある が，化膿連鎖球菌感染に打ける特定の疾患の病理 発生を考える上で重要な因子の 1 つになる可能
性もあるだろう。

\section{文献}

1) Adams, E.M., Gudmundsson, S., Yocum, D.E., Haselby, R.C., Craig, W.A., Sundstrom, W.R. (1985): Streptococcal myositis. Arch. Int. Med. 145, 1020-1023.

2) Åkesson, P., Schmidt, K.-H., Coony, J., Bjorck, L. (1994): M1 protein and protein $\mathrm{H}$ : IgGFc- and albumin-binding streptococcal surface proteins encoded by adjacent genes. Biochem. J. 300, 877-886.

3) Alouf, J.E. (1980): Streptococcal toxins (streptolysin $\mathrm{O}$, streptolysin S, erythrogenic toxin). Pharmacol. Ther. 11, 661-717.

4) Bessen, D.A., Fischetti, V.A. (1992): Nucleotide sequence of two adjacent $M$ or $M$-like protein genes of group A streptococci: different RNA transcript levels and identification of a unique immunoglobulin A-binding protein. Infect. Immun. 60, 124-135.

5) Caparon, M.G., Geist, R.T., Perez-Casal, J., Scott, J.R. (1992): Environmental regulation of virulence in group A streptococci : transcription of the gene encoding $M$ protein is stimulated by carbon dioxide. J. Bacteriol. 174, 5693-5701.

6) DiRita, V.J., Mekalanos, J.J. (1989): Genetic regulation of bacterial virulence. Annu. Rev. Genet. 23, 455-482.

7) Fischetti, V.A.(1989): Streptococcal M protein: molecular design and biological behavior. Clin. Microbiol. Rev. 2, 285-314.

8) Fischetti, V.A., Horstmann, R.D., Pancholi, V. (1995): Location of the complement factor $\mathrm{H}$ binding site on streptococcal M6 protein. Infect. Immun. 63, 149-153.

9) Frithz, E., Heden, L.-O., Lindhal, G. (1989): Extensive sequence homology between IgA receptor and $\mathrm{M}$ protein in Streptococcus pyogenes. Mol. Microbiol. 3, 1111-1119.

10) Gerlier, D., Varior-Krishnan, G., Devaux, P. (1995): CD46-mediated measles virus entry: a first key to host-range specificity. Trend. Microbiol. 3, 338-345.

11) Ginsberg, I. (1972): Mechanisms of cell and tissue injury induced by group A streptococci : relation to poststreptococcal sequelae. J. Infect. Dis. 126, 297-340.

12) Gomi, H., Hozumi, S., Hattori, C., Tagawa, F., Kishimoto, F., Bjorck, L. (1990): The gene se- 
quence and some properties of protein H.J. Immunol. 144, 4060-4052.

13) Hanski, E., Caparon, M.G. (1992): Protein F, a fibronectin-binding protein, is an adhesin of the group A streptococcus Streptococcus pyogenes. Proc. Natl. Acad. Sci. USA. 89, 6172-6176.

14) Hanski, E., Horwiz, P.A., Caparon, M.G. (1992): Expression of protein $\mathrm{F}$, the fibronectin-binding protein of Streptococcus pyogenes JRS4, in heterogeneous streptococcal and enterococcal strains promotes their adherence to respiratory epithelial cells. Infect. Immun. 60, 5119-5125.

15) Heath, D.G., Cleary, P.P. (1989): Fc-receptor and $\mathrm{M}$ protein genes of group A streptococci are products of gene duplication. Proc. Natl. Acad. Sci. USA. 86, 4741-4745.

16) Horstmann, R.D., Sievertsen, H.J., Knobloch, J., Fischetti, V.A. (1988): Antiphagocytic actibity of streptococcal M protein : selective binding of complement control protein factor $\mathrm{H}$. Proc. Natl. Acad. Sci. USA. 85, 1657-1661.

17) Hourcade, D., Holers, V.M., Atkinson, J.P. (1989): The regulators of complement activation (RCA) gene cluster. Adv. Immunol. 45, 381-416.

18) Kotzin, B., Leung, M., Kappler, J., Marrack, P. (1993): Supperantigens and their potential role in human disease. Adv. Immunol. 54, 99-166.

19) Lancefield, R.C. (1962): Current knowledge of type-specific $\mathrm{M}$ antigens of group A streptococci. J. Immunol. 89, 307-313.

20) Liszewski, K.K., Post, T.W., Atkinson, J.P. (1991): Membrane cofactor protein (MCP or CD46): Newest member of the regulators of complement activation gene cluster. Annu. Rev. Immunol. 9, 4310-455.

21) Lottenberg, R., Broder, C.C., Boyle, M.D.P., Kain, S.J ., Schroeder, B.O., Curtis III, R. (1992): Cloning, sequence analysis, and expression in Escherichia coli of a streptococcal plasmin receptor. J. Bacteriol. 174, 5204-5210.

22) McIver, K.S., Heath, A.S., Scott, J.R. (1995): Regulation of virulence by environmental signals in group A streptococci : influence of osmolarity, temperature, gas exchange, and iron limitation on emm transcription. Infect. Immun. 63, 4540-4542.

23) Miller, J.F., Mekalanos, J.J., Falkow, S. (1989): Coordinate regulation and signal transduction in the control of bacterial virulence. Science 243, 916-921.
24) Mollick, J.A., Miller, G.G., Musser, J.M. (1993): A novel superantigen isolated from pathogenic streins of Streptococus pyogenes with aminoterminal homology to staphylococcal enterotoxin B and C. J. Clin. Invest. 92, 710-719.

25) Nasr, A.B., Herwald, H., Muller-Esterl, W., Bjorck, L. (1995): Human kininogens interact with $M$ protein, a bacterial surface protein and virulence determinant. Biochem. J. 305, 173-180.

26) Norgen, M., Caparon, M.G., Scott, J.R. (1989): A method for allelic replacement that uses the conjugative transposon $\operatorname{Tn} 916$ : deletion of the emm6.1 allele in Streptococcus pyogenes. Infect. Immun. 57, 3846-3850.

27) Okada, N., Geist, R.T., Caparon, M.G. (1993): Positive transcriptional control of $m r y$ regulates virulence in the group A streptococcus. Mol. Microbiol. 7, 893-903.

28) Okada, N., Liszewski, M.K., Atkinson, J.P., Caparon, M. (1995): Membrane cofactor protein (CD46) is a keratinocyte receptor for the M protein of the group A streptococcus. Proc. Natl. Acad. Sci. USA. 92, 2489-2493.

29) Okada, N., Pentland, A.P., Falk, P., Caparon, M.G. (1994): M protein and protein F act as important determinants of cell-specific tropism of Streptococcus pyogenes in skin tissue. J. Clin. Invest. 94, 965-977.

30）大国寿士，五十嵐英夫，大江健二（1994）：あなど れないレンサ球菌感染症. 日本細菌学雑誌, 49, 759-767.

31）大国寿士（1990）：感染と免疫一溶連菌一，蛋白質 核酸酵素, 35, 2839-2851.

32) Pancholi, V., Fischetti, V.A. (1992): A major surface protein on group A streptococci is a glyceraldehyde-3-phosphate-dehydrogenase with multiple binding activity. J. Exp. Med. 176, 415-426.

33) Perez-Casal, J., Caparon, M.G., Scott, J.R. (1991): Mry, a trans-acting positive regulator of the M protein gene of Streptococcus pyogenes with similarity to the receptor proteins of two-component regulatory systems. J. Bacteriol. 173, 2617-2624.

34) Perez-Casal, J., Caparon, M.G., Scott, J.R. (1992): Introduction of the $\mathrm{emm}$ gene into an $\mathrm{emm}$-deleted strain of Streptococcs pyogenes restore its ability to resist phagocytosis. Res. Microbiol. 143, 549-558.

35) Perez-Casal, J.P., Okada, N., Caparon, M.G., Scott, J.R. (1995): Role of the conserved C-repeat 
region of the M protein of Streptococcus pyogenes. Mol. Microbiol. 15, 907-916.

36) Podbielski, A., Flosdorff, A., Weber-Heynemann, J. (1995): The group A streptococcal virR49 gene controls expression of structural vir regulon genes. Infect. Immun. 63, 9-20.

37) Scott, J.R. (1990): The M protein of group A streptococcus: evolution and regulation. In Molecular Basis of Bacterial Pathogenesis. B.H. Iglewski and V.L. Clark, editors. Academic Press, Inc., San Diego, CA. 177-204.

38）清水可方, 大山晃弘, 笠間和典, 宮崎増美, 大江 健二, 大河内康実 (1993): A 群溶血性連鎖球菌に よる toxic shock like syndrome の 1 例. 感染症学 雑誌, 67, 236-239.

39) Utiyama, T., Yan, X-J., Imanishi, K., Yagi, J. (1994): Bacterial superantigens. Mechanism of $\mathrm{T}$ cell activation by the superantigens and their role in the pathogenesis of infectious disease. Microbiol. Immunol. 38, 245-256.

40) Wang, B., Schlievert, P.M., Gaber, A.O., Kotb, M. (1993): Localization of an immunologically functional region of the streptococcal superantigen pepsin-extracted fragment of type $5 \mathrm{M}$ protein. J. Immunol. 151, 1419-1429.

41) Watanabe-Ohnisi, R., Aelion, J., LeGros, L., Tomai, M.A., Sokurenko, E.V., Newton, D., Takahara, J., Irino, S., Rashed, S., Kotb, M. (1994): Caracterization of unique human TCR $\mathrm{V} \beta$ specificities for a family of streptococcal superantigens represented by rhuematogenic serotype of $\mathrm{M}$ protein. J. Immunol. 152, 2066-2073.

42) Wexler, D.E., Chenoweth, E.E., Cleary, P.P. (1985): Mechanism of action of the group A streptococcal C5a inactivator. Proc. Natl. Acad. Sci. USA. 82, 8144-8148.

43) Willson, A.T. (1959): The relative importance of the capsule to the $\mathrm{M}$-antigen in determining colony form of group A streptococci. J. Exp. Med. 109, 257-270.

44) Whitnach, E. Beachey, E.H. (1985): Inhibition of complement-mediated opsonization and phagocytosis of Streptococcus pyogenes by $\mathrm{D}$ fragments of fibrinogen and fibrin bound to cell surface $\mathrm{M}$ protein. J. Exp. Med. 162, 1983-1997. 